\title{
The state of heritage and cultural property policing in England \& Wales, France and Italy
}

\author{
Abstract \\ Presenting a large threat to irreplaceable heritage, property, cultural knowledge and \\ cultural economies across the world, heritage and cultural property crimes offer case \\ studies through which to consider the challenges, choices and practices that shape \\ twenty first century policing. This article uses empirical research conducted in England \\ \& Wales, France and Italy to examine heritage and cultural property policing. It \\ considers the threat before investigating three crucial questions. First, who is involved \\ in this policing? Second, how are they involved in this policing? Third, why are they \\ involved? This last question is the most important and is central to the article as it \\ examines why, in an era of severe economic challenges for the governments in the case \\ studies, the public sector would choose to lead policing.
}

\section{Keywords}

Art crime, heritage and cultural property crimes, policing, problematization

\section{Introduction}

Globally, heritage and cultural property crimes pose considerable threats to property, knowledge, unique heritage and cultural economies. The extent of the threats grows further with the links that some of the crimes have to other illicit activities such as drugs, fraud and terrorism (Kerr, 2015; Mackenzie, 2005; Yates, 2014). Combatting these often cross-border crimes presents significant challenges for policing stakeholders and heritage and cultural 
property locations at local, national and international levels. This article uses empirical research conducted in three European case studies- England \& Wales, France and Italy- to examine who is involved in this policing, how they are involved in this policing and why they are involved in it. The role of the public police remains crucial in two of the case studies. However, the roles of other public sector stakeholders and the private sector are also central to this examination into an important area of policing that encapsulates many of the challenges, decisions and practices that shape and characterise twenty first century global policing.

Taking Brodeur's argument that comparative studies of policing are essential in understanding how policing works despite there being no ideal model (Brodeur, 1995:10), this research is not seeking an 'ideal' or one size fits all model from its analysis of different approaches in heritage and cultural property policing. Instead, it takes a more pragmatic 'learning from differences' approach (Hufnagel, 2013:14). With the future of policing appearing in many arena to constitute post-policing security formations defined by public and private interrelationships or private takeovers, this article analyses why heritage and cultural property crimes have been problematized (Foucault, 1984, 1988) more in two case studies than the third. Through this analysis, it answers an important question: in an era of economic problems and budget cutting, why are public police forces in Europe involved to such an extent in heritage and cultural property policing?

\section{Context}

There is a significant knowledge gap about the crimes and how to address them. Proposed figures for the extent of heritage and cultural property crimes lack empirical evidence; for example, cultural property objects are frequently not recorded separately from other property by the public police in many countries (Chappell and Hufnagel, 2014; Kerr, 2015). However, 
what is known is that heritage and cultural property crimes pose significant policing challenges at local, national and global levels owing to the cross-border activities, violence, shifting crime trends, links to other illicit activities, cultural and financial value of heritage and cultural property, and the belief that some locations and objects are soft targets (Chappell and Hufnagel, 2014; Kerr, 2015). Recent examples of crime trends about which we are aware include the thefts of metal art objects, Chinese art objects (particularly jade), and the continuing looting of antiquities that occurs in many source countries across the globe to be sold in demand countries (e.g. Brodie, 2014; Hardy, 2014; Mackenzie and Davis, 2014; Yates, 2014).

The limited amount of academic work on policing these illicit activities has highlighted that it is rare for public policing agencies to prioritise heritage and cultural property policing (Block, 2011; Chappell and Hufnagel, 2014; Dobovsek and Slak, 2013; Kerr, 2015). Chappell and Hufnagel (2014:3) sum up the situation: 'in general law enforcement officials in many parts of the world almost certainly remain today as ill prepared and ill equipped as their French counterparts were in the early 1900s when dealing with all forms of art crime.' Arguably, France, Italy and Spain are examples of countries whose governments prioritise heritage and cultural property policing (Block, 2011; Chappell and Hufnagel, 2014; Rush and Millington, 2015). It is for this reason that this study has examined France and Italy, as well as another in which a plural policing approach is taken, England \& Wales. Plural policing can be characterised by the lack of a locus of power in policing and the fact that the public sector might only be one part of a network of security providers or disappear altogether (Johnston and Shearing, 2003; Loader and Walker, 2007). This relates to Reiner's statement that 'policing' 'may be carried out by a number of different processes and institutional arrangements' (Reiner, 2010:4). It is also relevant to concerns about the role of the public police as private stakeholders take over many policing terrains (Ericson, 2007). The fact that a state-led public policing approach to heritage and cultural property policing is taken in France and Italy compared to 
the plural policing framework in England \& Wales provides a significant comparison to help generate more knowledge of this area of policing. This is particularly important as there is a lack of knowledge about policing models that exist in heritage and cultural property policing, and previous research has called for more in-depth investigation into differences between policing approaches taken in European countries (Kerr, 2015).

After the next section explaining the method, the article begins its analysis of heritage and cultural property policing by considering the threats posed by these crimes. It then examines who is involved in this policing and how. Lastly, it investigates why they are involved in this policing.

\section{Method}

A qualitative mixed methods approach was taken in the empirical research carried out in England \& Wales, France and Italy in 2015-2016. The data sources were interviews and observations. This approach has similarities with previous research on art theft in London that used interviews, observations and participant observations (Kerr, 2015). An inductive approach was taken, with the main conceptual and theoretical work occurring after the collection of the data. Despite this, the author's prior knowledge of previous research and his preconceived ideas about some approaches taken in Europe inevitably influenced the research.

Generic purposive sampling (Bryman, 2012) was employed in sampling the context (the countries chosen for their differing approaches) and in sampling the participants and locations within each case study. Not enough reliable empirical data is a major concern when conducting comparative policing research (Van Stokkom and Terpstra, 2016). Therefore, although subjectivity inevitably influenced the direct sampling strategy, this type of sampling was 
important because it resulted in an appropriate sample as the principle sources were public and private stakeholders involved in heritage and cultural property policing in the case studies.

The first and most important data source was 12 interviews. Interviewees included people who currently work (or used to) for London's Metropolitan Police Service's (MPS) Art and Antiques Unit (the only art and antiques unit in England and Wales), the Central Office for the Fight against Trafficking in Cultural Goods (OCBC) in France, and the Carabinieri Command for the Protection of Cultural Property (Carabinieri TPC) in Italy. In addition, the interviewees included the Policing Advisor to Historic England and other people whose work in insurance and loss adjusting, museums, private sector art detection and recovery makes them directly involved in heritage and cultural property policing. Regarding ethical considerations, informed consent was gained before each interview. Also, universal anonymity is employed for the interviewees where possible. The interviews were semi-structured in the sense that they were shaped by key themes: Threats to heritage and cultural property; Security challenges; Who is involved in this policing; How is this policing done; Private sector involvement; Motivations in the policing; The involvement of insurance; The future. The themes were influenced by previous research that has examined art crime policing, especially work that has considered who is involved in this area of policing (Block 2011, Chappell and Hufnagel, 2014; Kerr, 2014, 2015). For example, the themes share similarities with those in the interview schedule employed in research on policing of art theft in London (Kerr, 2014). The themes allowed for the three research questions to emerge as the most important themes, with the question 'why are they involved in the policing?' of particular importance. The themes also highlighted that to answer the three questions it was useful to include a focus on the threat as it enabled more understanding of policing contexts. 
In addition, observation fieldwork was carried out at 32 heritage and cultural property locations in London, Paris and Rome ${ }^{1}$. This provided useful supplementary data that helped to provide some triangulation (Bryman, 2012). A purposive sampling strategy concerning the type of location resulted in the author visiting more churches and cathedrals than other locations because of the emerging interview data and previous research that highlighted their vulnerability (Historic England, 2015; Kerr, 2015). However, it must be acknowledged that convenience sampling also played a role because the author was only in Paris for two days and could visit a limited number of locations in addition to conducting an interview. The author also attended two meetings of the All-Party Parliamentary Group on Cultural Heritage (APPG) established in the UK in September 2015.

There were limitations to the method. First, the subjectivity in the sampling strategy employed. Second, the interview data was one-sided as it came from people involved in policing rather than those who pose the threats. Third, the ability to produce generalisations was limited by choosing only three case studies. The research's scope was further reduced by its western European focus. Fourth, self-promotion could have shaped the interviewees' answers. However, the main benefit of the approach was that it enabled rich data to be collected from people directly involved in heritage and cultural property policing in three important case studies. Furthermore, focusing on only three case studies allowed for more analytical depth and detail than if a larger number had been chosen. In addition, choosing case studies with differing approaches to policing generated more knowledge that could be useful for other countries when considering their own approaches. Also, although limited in its scope, the observation data provided some triangulation. Concerning self-promotion in the interviews, it was important to be sceptical but also to accept that some truth existed.

\footnotetext{
${ }^{1}$ The 32 locations constituted 13 art galleries and museums (5 in London, 2 in Paris and 6 in Rome) and 19 churches and cathedrals ( 6 in London, 2 in Paris and 11 in Rome).
} 


\section{Findings and Discussion}

\section{Threat}

As awareness of the threats can enable more understanding of heritage and cultural property policing contexts, it is important to highlight that the empirical research findings showed that threats to heritage and cultural property in England \& Wales, France and Italy are extremely varied. Damage, theft and fraud are all current threats. There is a wide range of activities within these broad categories. These include theft from specific locations such as private residences, places of worship, museums/galleries, outdoor spaces, heritage sites, and when the objects are in transit; looting (including illegal metal detecting, known colloquially as 'nighthawking'); trafficking; iconoclasm/'theft by destruction', vandalism; and deception such as forgeries and false provenances. In addition, there are threats from accidental, anthropic, meteorological damage (Interviews, 18 June 2015, 24 June 2015, 30 September 2015, 8 January 2016, 29 January 2016, 26 February 2016, 10 March 2016; Ferrari, 2013; Rapicavoli, 2016; Fieldwork, 2015-6). A private art detective summed up the current main threats as: 'Thefts by deception and thefts by destruction' (Interview, 30 September 2015). Although it still happens, the stealing of works of art such as paintings is less attractive for some criminals for the following reason given by a loss adjuster: 'Now with the digitisation of images it is more difficult to dispose of art works' (Interview, 18 June 2015).

The empirical research findings also show that churches and private residences appear to be the most at threat locations in all three case studies, with churches being most vulnerable. People who work in heritage and cultural property policing in England \& Wales, France and Italy spoke of churches being victims of arson attacks, thefts, graffiti, and irrevocable damage to objects (Interviews, 24 June 2015, 26 February 2016, 10 March 2016; Rapicavoli, 2016). An officer in the German Bundeskriminalamt (BKA) also presented cases in Germany that 
included defecation on altars, damage and destruction of sculptures, damage to the inside of buildings, and relics being stolen (Karfeld, 2016).

The findings also support previous research that has highlighted the involvement of criminals who are organised and who often have links to other illicit activities and other groups of criminals (Interviews, 23 July 2015, 30 September 2015, 26 February 2016; Hill, 2016). Interviewees explained that people such as acquisitive thieves and insiders, fraudsters, fences, political groups, academics and the trade itself are involved as well (Interviews, 26 February 2015, 18 June 2015, 23 July 2015, 30 September 2015, 10 March 2016, 17 May 2016).

\section{Heritage and cultural property policing}

Despite moves towards post-policing security arena in many countries, this article's focus on the public police's role in policing heritage and cultural property crimes is not a case of state or 'police fetishism' in which the public police are assumed to be necessary for social order (Reiner, 2010:1; Shearing, 2006). It is a reflection of policing practice in France and Italy, where the state is leading heritage and cultural property policing and does so through their public police. Even in the co-production of heritage and cultural property policing in England \& Wales, public sector stakeholders still play significant roles despite there being no locus of power within the policing matrix.

In Italy, the Carabinieri Command for the Protection of Cultural Property (Carabinieri TPC) leads the public police's involvement in heritage and cultural property policing. With over 250 staff, it is the world's largest public or private policing stakeholder with a specific focus on heritage and cultural property. Started in 1969, the Carabinieri TPC is a Command of the

military police (Carabinieri) and led by a General. A 'structural' unit within the Ministry of Cultural Heritage and Activities and Tourism (MiBACT), it has three key areas: the 
Operational department, the regional units (13 across Italy), and the Command Office. One of the sections in the Command Office is the Data Processing Unit which takes a lead in the intelligence gathering and maintains the Leonardo database of stolen and lost cultural property objects. In June 2016, there were 1,216,379 stolen objects and 6,038,165 objects in total described on the database (Rapicavoli, 2016). While non-specialist officers are made aware of the unit and the database, and non-TPC Carabinieri units also recover cultural objects, the Carabinieri TPC is the lead nationally and when cooperating internationally. It has outreach teams which educate people about its activities and give advice for security. It trains and works with many other agencies and organisations nationally and internationally. Additionally, it offers heritage and cultural property support within Italian military operations in conflict zones such as Iraq (Interview, 29 January 2016; Ferrari, 2013; Rush and Millington, 2015; Spadari, 2015).

Private sector stakeholders are also involved in heritage and cultural property policing in Italy. These include insurance companies, loss adjusters, the private guarding sector in some cultural locations, and security consultancy/ technology companies. However, the Carabinieri TPC is an example of state-led policing that continues to be deemed by the Italian government to be viable despite its high financial costs. Reiner's point that 'policing is at the heart of the functioning of the state, and central to an understanding of legal and political organisation' (Reiner,1992:762) fits the Italian approach as it is far from the plural policing frameworks that often characterise post-policing security terrains globally. It is also a reflection of the historic and political contexts of policing in Italy (especially the Italian public police's roots in the Napoleonic occupation of the peninsula in 1800 when policing was an important part of the highly-centralised administration system introduced), the Italian legalistic approach and the lack of a clear distinction between military and civil issues in policing (Dunnage, 1997). Rather than releasing power in a plural policing framework such as nodal governance (Johnston and 
Shearing, 2003; Wood and Dupont, 2006), power is retained by choosing to be very involved in policing. Even a state-centred policing theory such as anchored pluralism (Loader and Walker, 2006), in which the state retains a controlling role within the plural policing arena, does not sufficiently reflect it. It is more of a 'monopolistic' model of policing (Crawford, 2006:544). However, in line with the fact that private and public policing both take risk based approaches (Ericson and Haggerty, 1997), the approach taken by the Carabinieri TPC is an intelligence-led one with a focus on proactive policing and preventative measures. For example, its Data Processing Unit monitors the art market, conducts online searches and verifies security measures in cultural locations (Interview, 29 January 2016; Rapicavoli, 2016; Rush and Millington, 2015; Spadari, 2015).

In France, the Central Office for the Fight against Trafficking in Cultural Goods (OCBC) leads the public police's involvement in heritage and cultural property policing. It was set up in 1997 after previously being the Central Office for the Repression of the Theft of Works and Objects of Art established in 1975. The OCBC has 25 staff. In contrast to the Carabinieri TPC, the OCBC has both civil and military police officers, employing 10 Police Nationale officers, 10 Gendarmerie officers and five administration agents. It has specific sections: the Secretariat, the Database Unit which gathers intelligence and maintains the Treima database of stolen heritage and cultural property objects, the External Relations/Training group, the Operational section consisting of three investigation groups, and a section of liaison officers who work with the Ministry of Culture and Communication and the High Council of Voluntary Sales. It also has a network of 34 'correspondants' (probably best described as liaison officers) throughout France. As well as acting with other Gendarmerie and Police Nationale, the OCBC works with Europol, Customs, foreign public police services, Interpol, the art market, insurance companies, owners, international organisations, Interior Security Attaches, the Ministry of Culture and Communication, Ministry of Justice and Ministry of Foreign Affairs (Interview, 
10 March 2016; Gauffeny, 2014). Although smaller in scale to the Italian public policing approach, this is another example of predominately state-led policing with the OCBC at the centre. This has clear links to the history of French policing and the 'administrative culture of top-down centralisation' which still exists and is characterised by its 'rigidity' (Brodeur, 2010:51). Moreover, the use of military police again highlights the continental lack of distinction between civil and military issues. It is also a reflection of where the crimes occur. An OCBC officer explained: 'Lots of it happens in rural areas (areas gendarmes police in France)' (Interview, 10 March 2016).

In England \& Wales, there is no national public policing unit for heritage and cultural property crimes. As with policing art theft in London (Kerr, 2015), a nodal governance framework (Johnston and Shearing, 2003) is the most suitable theoretical tool to examine the wider field of heritage and cultural property policing in England \& Wales. A co-production exists with no public or private stakeholder taking an overall leading or 'command' role in the way that happens with the Carabinieri TPC and the OCBC. With no locus of power, it is made up of private and public sector stakeholder 'nodes'. Even the insurance companies who are involved in all eight dimensions of governance set out by Johnston and Shearing (2003) are still far from being a locus of power and indeed show no appetite for this role (Interview, 30 September 2015).

The policing framework is currently made up of the private and public guarding sector, the Department for Culture Media \& Sport and Arts Council England (including the National Security Adviser), Crown Prosecution Service, Historic England, English Heritage, National Crime Agency, HM Revenue and Customs, Border Force, Maritime and Coastguard Agency, Coroners (for the reporting of treasure finds), heritage and cultural property locations (e.g. the British Museum who run the Portable Antiquities Scheme), security consultancy/technology companies, private recovery and investigative companies/detectives, databases including the 
Art Loss Register (ALR) (a global private sector database based in London), insurance companies and those who work with them such as loss adjusters, Interpol, Europol, public policing stakeholders in other countries, Heritage Crime Liaison officers in county forces plus a very small number of other police officers with cultural property crime expertise, and London's Metropolitan Police Service's (MPS) Art and Antiques Unit (AAU).

First set up in 1969, the AAU is a MPS resource and must therefore have a 'London footprint'. It takes the investigative lead for the theft of exhibition items from London's museums, public galleries and archives and for the sale of fake and forged works of art significantly impacting upon London. Additionally, the AAU deals with gathering evidence and intelligence for overseas public police and judicial authorities on matters relating to stolen cultural property on the London art market. Where possible the AAU focuses on a prosecution first and foremost but recognises that recovery of cultural property is an important part of any investigation. The AAU works with other policing and government agencies, and is part of the National Police Chiefs' Council's (NPCC) National Heritage and Cultural Property Crime Working Group. Furthermore, it works with non-government agencies and is often supported by experts from academia, museums and the trade organisations. At the time of the interviews, the AAU consisted of one Detective Sergeant, three Detective Constables and one member of Police staff (who maintains the London Stolen Art database (LSAD)) (Interviews, 8 January 2016, 29 April 2016). The LSAD is a small database compared to the ALR's database which the AAU uses. With London being home to the third biggest art market in the world (Artprice, 2016) and the 'gravitational pull' that this can have for stolen or fraudulent cultural property objects (Ratcliffe, 2016), the AAU's role is important.

The lack of a national unit in England \& Wales is a major difference compared to Italy and France. A national unit has been proposed before, and even by the public police themselves in the Heritage and Cultural Property Crime National Policing Strategic Assessment in November 
2013 (ACPO, 2013). An interviewee who works closely with the public police said that a national unit could be a useful addition to the policing framework (Interview, 26 February 2016). Reflecting the existing policing framework in England \& Wales, it could benefit from being multi-agency and would also not need to take a 'command' role in the manner of the Carabinieri TPC and OCBC. An interesting model could also come from the Serious Fraud Office (SFO). Unusually for the UK, the SFO are involved in intelligence, investigation and prosecution (SFO, 2016). An example for how to fund the Unit could come from the National Wildlife Crime Unit (NWCU) which secured funding in 2016 until 2020 from a range of public sector funders (NWCU, 2016).

The NPCC's former lead for Heritage and Cultural Property Crime, along with Historic England's Policing Advisor have pushed for and succeeded in persuading each county police force to have a Heritage Crime Liaison officer (Interviews, 26 February 2016, 17 May 2016). The presence of at least one officer in county forces who has some knowledge of heritage and cultural property crime or, at least, some awareness of who to turn to should they think heritage and cultural property crime is involved, is an improvement on what was until recently the dire situation where many county forces did not have an officer with basic training or awareness of the crimes. In addition, for over four years Historic England's Policing Advisor has conducted heritage crime outreach programmes for as many as 10,000 practitioners, including many police officers. According to the Policing Advisor, these people should now have at least 'basic level awareness and understanding' of heritage crime (Interview, 26 February 2016). New technologies such as an app which informs officers that they are passing by a site of heritage or cultural property significance have also been developed. The NPCC's former lead for Heritage and Cultural Property Crime and Historic England's Policing Advisor have tried to push for more public policing and to create and maintain networks with public and private sector stakeholders (Interviews, 26 February 2016, 17 May 2016). Despite this recent increase 
in public policing, much heritage and cultural property policing is conducted by the private sector stakeholders previously listed in the nodal governance framework. This is in line with the argument proposed by Shearing that it is 'implausible to conceive of the state as the sole auspice of governance' (Shearing, 2006:27) and highlights the significant differences in this policing arena compared to France and Italy.

One of the clearest differences is that the main database used in England \& Wales, the ALR's database, is in the private sector compared to the Leonardo database in Italy and the Treima database in France which are run by the Carabinieri TPC and the OCBC respectively. An employee of this international database said that the database is better placed in the private sector to avoid nation states' issues (Interview, 23 July 2015). Although unsurprising that the interviewee would argue this owing to where they work, the public police's use of the database highlights the acceptance and use of the private sector in this policing arena in England \& Wales compared to France and Italy.

In a post-policing security arena characterised by public/private interrelationships and networks, questions arise on the one hand over whether the public police are actually required in this arena, and, on the other, why the public police are not more involved. In England \& Wales, the public police are still needed as they remain a 'specialist resource' with powers other policing agencies do not have (Brodeur, 2010; Reiner, 2013). These include their investigation powers and their potential capacity in intelligence gathering, and the letters of authorisation for insurance companies to pay rewards to aid recoveries of art objects.

Even with this role as a 'specialist resource' and more recent attention such as the new Heritage Crime Liaison Officers, the differences between the approach in England \& Wales and the two continental case studies are large, as this section has shown. Why the public police are not more involved in England \& Wales will be considered in the next section. Differences in approaches 
are also evident when widening the lens of investigation to other countries. For example, Belgium closed its public police art crimes unit in 2016 (Interview, 10 March 2016). Shearing's proposition that 'nodal policing is here to stay' (Shearing, 2015:11) is very appropriate for the arena of heritage and cultural property policing in England \& Wales. However, although nodal policing might offer a very suitable and effective alternative in many countries, in France and Italy the public sector want to continue to lead this policing and it appears that to conceive of 'the state as the sole auspice of governance' (Shearing, 2006:27) is entirely plausible for them in heritage and cultural property policing. The next section considers why.

\section{The problematizing of heritage and cultural property crimes}

In investigating why the public police still have a leading role in heritage and cultural property policing, it is important to examine how and why the crimes are considered or not considered to be a problem. Foucault's work on problematization is extremely helpful as he was not searching for the one 'valid' answer to an issue but rather trying to understand the processes and development in which an issue becomes a problem and how it is then focused on (Foucault 1984, 1988). The practices involved in this process shape how people view an existing issue. Important aspects are that, first, problems (especially policy problems) often have to be constructed, and, second, that this can be a slow process which leads to the present having a significant history (Ball, 2012:149; Flynn, 2005:45; Miller and Rose, 2008). Extremely relevant to this article, Bacchi (2012) argues that comparisons of problematizations show how particular combinations of processes can lead to an issue developing into a problem in one case but not in another. In examining the problematization of heritage and cultural property crimes in the three case studies, this section considers the processes that result in such a large public policing response in a country such as Italy compared to a limited public policing response in another such as England \& Wales. 
The Italian government prioritises heritage and cultural property crimes more than other European governments. This is reflected in the size and resources of the Carabinieri TPC and the scope of its operations in Italy and abroad. The huge amount of heritage and cultural property in Italy is a simple reason for this prioritisation (Rush and Millington, 2015). For example, a museum curator explained that a city such as Rome can be described as 'an openair museum' (Interview, 24 June 2015). An ex-head of the Carabinieri TPC also highlighted the important point that the safeguarding of the nation's heritage is included in the fundamental principles of Italy's constitution (Interview, 29 January 2016). Italian and British interviewees explained that another reason is that in Italian law any antiquity recovered from Italian soil belongs to the state, so when 'nighthawkers' or looters (tomborali) remove objects from the earth, they are stealing from Italy rather than a private landowner (Interviews, 29 January 2016, 26 March 2016; Rush and Millington, 2015). The wider historical and political context of policing in Italy is also important. The highly-centralised administration system introduced in the Napoleonic occupation in 1800 continued into postunification Italy. Since unification, public policing has had a crucial role in authorities' attempts to maintain their power when feeling vulnerable to political opposition (Dunnage, 1997). This can help to explain how and why the traditional views of the central role of the state and its assertion of its monopoly over policing still hold ground in Italy compared to states with different histories such as England \& Wales who have been much keener to embrace neo-liberal thought and leave areas of policing to other sites of governance.

The Italian state sees wider benefits from the prioritisation of heritage and cultural property. These were evidenced in the Ministry of Cultural Heritage and Activities and Tourism's (MiBACT) announcement in January 2016 that there would be 300 million euros made available for 241 interventions over three years. This was in addition to spending 360 million euros in five southern regions. Part of this money is to be used on security; for instance, 50 
million euros is allocated to a special security project (MiBACT, 2016a). However, as well as the protection and recovery of heritage and cultural property, this level of prioritisation also intends to have potential economic, cultural and political benefits, and even includes the aim to help against wider security threats from terrorism (MiBACT, 2016b; ICCROM, 2016a; ICCROM, 2016b).

With clear links to Bacchi's argument that 'Governing takes place through particular problematizations' (Bacchi, 2012:5), by problematizing heritage and cultural property crimes as being important for economic, political, security and cultural reasons, and publicising that they are being dealt with by one of the policing arms of the state, the position of the state is reinforced as well as demonstrating to the population that the government care about preserving the 'Italian' cultural identity (however wide ranging the identities within this identity might actually be). During the current turbulent economic, social and political era, the recent government (2014-16) of Prime Minister Renzi was enabling itself to assert its governance through the problem of heritage and cultural property crime. The discourse employed is crucial as the message conveyed is that the Carabinieri TPC is protecting and recovering heritage and cultural property and it is the Italian people who stand to benefit from their own cultural heritage and from cultural economies. The Carabinieri TPC's 'symbolic power' (Brodeur, 2010:65) is very significant, especially as parallel to this discourse the recent government pushed for the private sector to help fund cultural locations (MiBACT, 2016c:3) and some cultural locations in Italy already use the private guarding sector (Fieldwork, 24-30 June 2015).

Part of the process of the government asserting itself through its wider cultural policy and heritage and cultural property policing are the public relation exercises such as the Carabinieri TPC holding well publicised and popular exhibitions throughout Italy to promote its activities and highlight successes (Fieldwork, 30 June 2015; Rush and Millington, 2015). In addition, as well as using the media during investigations, it promotes its activities through national and 
international documentaries (Fieldwork, 29 June 2015; Butterworth, 2010; MiBACT, 2016d; Rush and Millington, 2015; RAI, 2015). These activities also help to educate the viewers and listeners about heritage and cultural property crimes and dispel some of the myths that can lead to the public viewing the perpetrators as having some glamour and perceiving the crimes as lacking importance. Although these activities are positive, the Carabinieri TPC's use of press conferences can be problematic. An example is a case in which the Carabinieri TPC seized some previously stolen paintings before returning them to a good faith purchaser. While the case was ongoing, the Head of the Carabinieri TPC and the Minister of Culture and Tourism held a press conference when perhaps a less demonstrative approach could have been more appropriate because the good faith purchaser was the person who originally contacted the Carabinieri TPC and they did not want publicity for fear of future theft (Interview, 23 July 2016). This is important if people are to be encouraged to contact the public police.

The Carabinieri TPC's collaboration and activities abroad also globally promote the image of Italy as a leader in the protection of heritage and cultural property. An interesting part of this 'soft power' cultural diplomacy is that, in addition to successfully repatriating items back to Italy, they have also returned objects themselves. In 2012 alone, the Carabinieri TPC recovered and returned 149 objects from Italy to other countries (Ferrari, 2013). An ex-head of the Carabinieri TPC also highlighted it was Italy that successfully proposed the global initiative to send UN peacekeepers or 'Blue Helmets of culture' to protect heritage sites in conflict zones (Interview, 29 January 2016). The same interviewee explained that the differences in Italy concerning the approach towards heritage and cultural property compared to other countries leads 'to completely different approaches to the issue' (Interview, 29 January 2016).

The level to which heritage and cultural property crimes in England \& Wales are constructed to be a problem is very different from in Italy. A reason that can explain, at least to an extent, the lack of prioritisation shown by the government and the public police towards heritage and 
cultural property crimes is the belief that arguably there are fewer heritage and cultural property crimes than in Italy (although this is difficult to confirm owing to the lack of statistics) (Interview, 30 September 2015). In addition, in England \& Wales, items found in the ground do not belong to the state but to the landowner, with treasure finds an exception (Interview, 26 February 2016). Another significant reason is that private stakeholders such as insurance companies are very involved in heritage and cultural property policing and can therefore be seen by the public police and the public (at least until an incident needs to be reported) to be addressing the problem. A loss adjuster said that, from a cynical point of view, the public police can argue that the victim is insured and so leave an insurance company to deal with the incident (if indeed the person has insurance) (Interview, 18 June 2015). Nevertheless, there is more to the processes behind the prioritisation than these reasons.

Similar to the Italian government's awareness of the 'value' of the cultural economy, the UK government and local councils have long used culture as an economic tool and been quick to promote this (Cinti, 2008). In addition, they have been turning to the private guarding sector for national museums and galleries (Fieldwork, 2015-16). It is important to note that in the UK there are serious concerns over the nature of this privatisation. In 2015, these matters led to industrial action for over 100 days at the National Gallery in what was, according to an interviewee, a test case for the potential 'rollover of mass privatisation' (Interview, 12 February 2015; Fieldwork, 30 May 2015).

However, it is when comparing the extent of the Italian government's ambitious strategy to use heritage and cultural property as a driver for cultural, political and security gains, that large differences can be observed. This is particularly the case in the UK government's public policing approach compared to the Italian approach. The activities of the public police in heritage and cultural property policing in England \& Wales have often received little attention despite some significant successes. This relates to the argument put forward by Miller and Rose 
(2008:14) that problems 'have to be constructed and made visible, and this construction of a field of problems is a complex and often slow process. Issues and concerns have to be made to appear problematic, often in different ways and in different sites, and by different agents'. These processes have taken place in France and Italy, and continue to do so. Conversely, in England \& Wales there has not been a sufficiently similar creation of a 'history of the present' (Flynn, 2005:45) in which many types of heritage and cultural property crimes nationally and internationally are constructed to be a problem for the government, the public police and the public. This is despite the efforts of academics and professionals in the field. For example, according to someone who works in the policing framework in England \& Wales the public police's not recording of stolen cultural property objects separately from other property leads to a lack of statistics and therefore understanding (Interview, 26 February 2016). Diplomatically, they argued that the present situation presented an 'opportunity to review and improve' (Interview, 26 February 2016). Extra data could help gain more prioritisation for the crimes and assist in combatting them. For instance, in emphasising the scale of heritage/cultural property metal thefts, Historic England highlighted data from the Ecclesiastical Insurance Group for the five years up to April 2014, which showed that in England more than 6700 churches and 42 commercial heritage properties (e.g. museums and country houses) were victims of metal thefts (Historic England, 2015). The data demonstrated both the alarming threat of metal theft and the fact that churches are especially targeted. In addition, the same interviewee explained that since 1 February 2016 sentencing guidelines concerning heritage assets include the opportunity to impose a greater penalty (Interview, 26 February 2016). A differentiation in the recording process between heritage/cultural property metal theft and other forms of metal theft could help to make use of the potential enhanced sentence.

Despite this, there has been some specific recent UK government focus on antiquities being damaged and/or looted in Syria and northern Iraq, and concerns over allegations that looted 
objects are being used to fund Daesh/ISIS (Burrowes, 2016). The government's recently established Cultural Protection Fund of $£ 30$ million for projects to support countries in global conflict zones (House of Lords, 2016), the Ratification of the 1954 Hague Convention for the Protection of Cultural Property in the Event of Armed Conflict (House of Commons Library, 2017) and the APPG set up in September 2015 (Fieldwork, 18 April 2016, 27 June 2016; Parliament, 2016) are signs that the government is becoming more aware of the destruction of heritage, looting and the arrival of objects onto the global art and antiquities market, of which London is a global hub. However, these recent moves show that while a problem is now to an extent being constructed, it is being done so primarily as a problem that exists abroad in conflict zones.

Meanwhile, within the UK and abroad in non-conflict zones, many of the issues have still not received adequate attention. The emerging policy focus on global conflict zones could miss the wider problem regarding looting. For example, academics have already shown that this specific looting from Syria and northern Iraq is not new and that the scale of looting around the world is immense and happens in many countries that are not in conflict zones (e.g. Brodie et al., 2000; Mackenzie and Davis, 2014; Rush and Millington, 2015; Yates, 2014) and proposed that dealers and auction houses should be a key focus (e.g. Brodie, 2009; Mackenzie and Green, 2009; Tsirogiannis, 2016). Moreover, an interviewee who works in heritage and cultural property policing in England \& Wales argued that it is also important to focus on heritage and cultural property crimes happening nationally and not lose sight of the value of heritage sites and objects found within the country (Interview, 26 February 2016). An OCBC officer argued the same point concerning France and explained that a heritage site in France should receive the same attention as one in Syria or Iraq: 'The field next door is the same as ISIS Daesh' (Interview, 10 March 2016). 
The MPS AAU has used the media for appeals during investigations and curated a very successful exhibition 'Metropolitan Police Service's Investigation of Fakes and Forgeries' in 2010 in collaboration with the V\&A Museum in London (Fieldwork, 28 January 2010). There has been some other limited coverage of schemes, appeals and recoveries in the media (e.g. Cambridgeshire Constabulary, 2016; Hertfordshire Police, 2015; West Mercia Police, 2016). However, there could have been more, especially in the current era in which public police communication offices or 'promo-police' (McLaughlin, 2007:104) work hard in trying to persuade the public that the public police have an important role in numerous policing terrains despite questions over their effectiveness (Brodeur and Shearing, 2005; Reiner, 2010). While the 'promo-police' in Italy make frequent use of the Carabinieri TPC, in England \& Wales the large successes and also the links in some of the cases to crimes such as terrorism, fraud and drugs could have been (and could still be) promoted more, particularly considering the culturally and financially significant recoveries (e.g. Chinese jade objects and works by Goya, Munch and Vermeer) that have been made by the MPS AAU and some county forces. This could help promote what the public police have been doing and the type of people they have faced. For example, the significant role of violence, damage and pain within many of the crimes could be emphasised more to help change views of the crimes as being non-violent and affecting wealthy people's or institutions' insured property which can lead to the processes that result in them not being seen as a problem by the wider public and some public police. According to a loss adjuster, in England \& Wales, outside of London potentially this has led to a lack of investigation even when public police have been given information by private stakeholders (Interview, 18 June 2015). This relates to the lack of other outreach activities to educate people about the realities of the crimes and previous successes. The fact that this has not happened, illustrates how, in contrast to Italy, nationally UK governments have not wanted to prioritise heritage and cultural property crimes and have certainly not wanted to assert 
themselves through national policing of the crimes. An interviewee who works with the public police in England \& Wales highlighted the need to have Police and Crime Commissioners (officials elected by the public to hold the public police to account) in England \& Wales who support the tackling of heritage and cultural property crimes in their force areas (Interview, 17 May 2016). As the Commissioners could be vulnerable to populist policing agenda fed by media representations (Reiner, 2013), the construction of the problem in the public imaginary is crucial.

In France, the OCBC has an External Relations Unit of two officers who try to engender cooperation, give presentations nationally and internationally, speak at universities, run seminars for the National School of Magistrates, highlight the importance of protecting heritage and cultural property, explain to people how to use the law and which tools to employ, and educate the public about crimes. They hold press conferences for investigations and publicise the main issues (Interview, 10 March 2016). An OCBC officer spoke about a recent booklet with guidelines concerning what archaeologists must do when they encounter a looted location. The Officer said that this widely distributed booklet had resulted in many more reports to the police/gendarmerie, from one to 99 per year in 2015 (Interview, 10 March 2016). This activity has similarities with the handbook that the Carabinieri TPC created in 2013 for the Vatican. The handbook has guidelines to improve the protection of ecclesiastical cultural heritage and it was designed to be distributed throughout the world (Interview, 24 June 2015; Ferrari, 2013). Similar to Italy, the French 'promo-police' use the OCBC for promotional purposes; for example, the Police Nationale have used the OCBC in their recruitment videos (Police Nationale Recrutement, 2016) and they have promoted their work through UNESCO's media (UNESCO TV, 2011).

The OCBC interviewee believed that the OCBC has had to work hard to 'legitimize its existence'. The officer argued that heritage and cultural property have not been 'high priority' 
(Interview, 10 March 2016). This, however, should be put into perspective when viewed in relation to most countries as the OCBC's 25 officers and 34 'correspondants' (Interview, 10 March 2016) make it one of the largest art crime units in the world. Furthermore, they did add that their activities are 'now being more recognised by government and the public' (Interview, 10 March 2016). An exhibition about the OCBC's work on its 40th anniversary in 2015 at the Interior Ministry is evidence of this promotion of their work. The interviewee thought that as many as 20,000 people visited the exhibition in two days (Interview, 10 March 2016). President Hollande's announcement of a 5\% increase in the culture budget for 2017 and that culture will be a 'priority' has similarities with the Italian government's approach of prioritising culture, especially in the discourse with phrases such as 'Artists are the pride of our country' (Le Monde, 7 July 2016). Although not to the same extent as in Italy, heritage and cultural property crimes are constructed to be a problem in France. The OCBC has 'symbolic power' (Brodeur, 2010:65) in its role and it is an example of the 'top-down centralisation' that continues to exist in policing in France (Brodeur, 2010:51; de Maillard and Roche, 2004). This contrasts with England \& Wales' openness to other sites of governance in policing and the state's lack of desire to have a national unit.

There has also been an interesting recent legal change in France. Metal detecting remains illegal without a specialist permit, but ownership rights have changed. On any land purchased before July 2016, the previous system remains of the landowner and finder being able to claim a found object. However, for finds on land purchased since July 2016, if the 'Territorial Commission' decides the object is an 'archaeological artefact' then the state keeps it (ECMD, 2016). This move signals a shift more towards the Italian approach to finds and, in doing so, enhances the state's role with heritage and cultural property. 


\section{Conclusion}

This article has examined differing approaches in heritage and cultural property policing, from the state-centred policing model in France and Italy to plural policing in England \& Wales. It is understandable why the Italian monopolistic public policing model is proposed as the most effective (Rush and Millington, 2015). However, although the Italian model is effective in many ways for Italy despite its high financial cost, this article has shown that there is little value in recommending it as the ideal model for other countries. This is because to propose that the Italian model be used in countries such as England \& Wales would neglect the significant differences in relations between civil society and state and differing states' approaches to public policing, the laws concerning finds, countries' constitutions (if they have one), as well as the approaches to heritage and cultural property policing. The Italian state has the wider motive to assert its governance through the problem of heritage and cultural property crimes and its use of the Carabinieri TPC goes beyond this actual policing.

Despite there being no ideal model to propose, the three models provide some lessons that could be useful for many countries. First, irrespective of whether the approach taken has the state as the locus of power or not, public police crime recording processes could allow for the specific recording of heritage and cultural property. This is a strength of the French and Italian models and a current weakness in England \& Wales that could be adapted. Second, while the 'symbolic power' (Brodeur, 2010:65) of the public police is less important in heritage and cultural property policing in countries such as England \& Wales, if the public police remain a 'specialist resource' (Brodeur, 2010; Reiner, 2013) then some public police presence is necessary in countries' policing frameworks for heritage and cultural property despite private policing being able to do much of this policing. A national unit, even if it were small, could be a useful resource for this presence. It could share intelligence nationally and internationally and would not need to have a 'command' role like the Carabinieri TPC and OCBC. 
Highlighting the links heritage and cultural property crimes have to other illicit activities could help in proposing the need for a national unit to governments and public sector stakeholders. Third, a lesson from all three case studies is that while more attention on the source locations of stolen heritage and cultural property objects is a positive, there could also be more focus on the demand locations and markets. A fourth lesson comes from the French and Italian models. The lesson is the importance of the processes in the problematizing of the crimes. As well as looking to the future, one way to do this is to continue to create a different 'history of the present' (Flynn, 2005:45), especially in countries where the crimes have received less attention. This could help to persuade governments, public sector stakeholders such as public police officers and customs officials, private sector stakeholders and the public that the crimes require an adequate amount of policing attention, whether the state is the locus of power or not within this policing. The increasing number of academics and professionals conducting research globally is an obvious positive. The work of the Carabinieri TPC in Italy and OCBC in France demonstrates that a crucial part of shaping the processes is to show and emphasise the effects of heritage and cultural property crimes. As well as highlighting the impact of activities such as terrorism, drugs and fraud that have links with heritage and cultural property crimes, it is also important to stress the uniqueness of much heritage and cultural property and the potential loss to cultural knowledge, the cost to the cultural economy and the significant role of violence within many of the crimes.

\section{References}

Artprice.com (2016) http://imgpublic.artprice.com/pdf/rama2016_en.pdf (accessed 11 October 2016) 
Association of Chief Police Officers (ACPO) Heritage and Cultural Property Crime National Policing Strategic Assessment (2013)

http://www.acpo.police.uk/documents/crime/2013/201311-cba-heritage-cult-prop-stratassmnt.pdf (accessed 10 April 2016)

Bacchi C (2012) Why Study Problematizations? Making Politics Visible. Open Journal of Political Science. Vol.2, No.1,1-8

Ball S (2012) Global Education Inc.: New Policy Networks and the Neoliberal Imaginary. Abingdon:Routledge

Block L (2011) European Police Cooperation on Art Crime: A Comparative Overview. Journal of Art Crime, Spring 13-25

Brodeur J-P (ed) (1995) Comparisons in Policing: an International Perspective. Avebury:Aldershot

Brodeur J-P (2010) The Policing Web. New York:Oxford University Press

Brodeur J-P and Shearing C (2005) Configuring Security and Justice. European Journal of Criminology, 2(4):379-406.

Brodie N (2014) The Internet market in Precolumbian antiquities. In: Kila J and Balcells M (eds), Cultural Property Crime: An Overview and Analysis on Contemporary Perspectives and Trends. Leiden:Brill

Brodie N, Doole J, and Watson P (2000) Stealing history: The Illicit Trade in Cultural Material. MacDonald Institute for Archaeology Research, Cambridge

Bryman, A (2012) Social Research Methods (4th Edition) Oxford:Oxford University Press Burrowes D (2016) http://davidburrowes.com/content/cultural-heritage-appg (accessed 23 July 2016)

Butterworth A (2010) The Carabinieri Art Squad BBC Radio 4 http://www.bbc.co.uk/programmes/b00sm8tn (accessed 9 May 2016)

Cambridgeshire Constabulary (2016) http://www.cambspolice.co.uk/news/newsitem.asp?NewsID=9015 (accessed 16 July 2016)

Chappell D and Hufnagel S (2014) (eds) Contemporary Perspectives on the Detection, Investigation and Prosecution of Art Crime. Farnham:Ashgate

Crawford A (2006) Networked Governance and the Post-Regulatory State? Steering, Rowing and Anchoring the Provision of Policing and Security. Theoretical Criminology Vol.10(4):449-479;1362-4806

de Maillard J and Roche S (2004) Crime and Justice in France Time Trends, Policies and Political Debate. European Journal of Criminology Vol.1(1):111-151 
Dobovsek B and Slak B (2013) Criminal Inspectors and Art Crime Investigation in Slovenia. Journal of Art Crime. Fall 2013

Dunnage J (1997) The Italian Police and the Rise of Fascism: A Case Study of the Province of Bologna (1897-1925). Westport, CT:Praegar

Ericson R (2007) Crime in an Insecure World. Cambridge:Polity Press

Ericson, R and Haggerty, K (1997) Policing the Risk Society. Oxford:Clarendon Press

European Council for Metal Detecting (2016) https://ecmd.eu/2016/09/04/metal-detecting-infrance-a-new-law/ (accessed 15 October 2016)

Cap. Ferrari (2013) The Carabinieri Cultural Heritage Protection Service

Flynn T (2005) Foucault's mapping of history. In: Gutting G (ed), The Cambridge companion to Foucault (2nd Ed.). Cambridge:Cambridge University Press

Foucault M (1984) Polemics, Politics and Problematizations, based on an Interview conducted by Paul Rabinow. In: Rabinow P (ed) (1998) Essential Works of Foucault, Vol.1 "Ethics". The New Press http://foucault.info/doc/foucault/interview-html

Foucault M (1988) The Concern for Truth. In: Kritzman, L (ed) Michel Foucault: Politics, Philosophy, Culture. Interviews and Other Writings, 1977-1984. New York:Routledge.

Gauffeny S (2014) OCBC. La protection des biens culturels contre le pillage, le vol et le trafic illégal: Action, mise en œuvre et rôle des archives numériques. PDF Morocco 9-11 January 2014

Hardy S (2014) Threats to Cultural Heritage in the Cyprus Conflict. In: Grove, L and Thomas S (eds) Heritage Crime. Progress, Prospects and Prevention. Basingstoke:Palgrave Macmillan Hertfordshire Police (2015)

https://www.herts.police.uk/advice/rural_policing/heritage_crime-1/heritage_watch.aspx (accessed 27 April 2016)

Hill C (2016) Conference Paper at Art, Crime and Criminals: Painting Fresh Pictures of Art Theft, Fraud and Plunder Workshop, Queen Mary University, London 21 May 2016

Historic England (2015) New Guidelines Target Heritage Thieves. https://historicengland.org.uk/whats-new/news/new-guidelines-target-heritage-thieves (accessed 26 April 2016)

House of Commons Library (2016) http://www.legislation.gov.uk/ukpga/2017/6/contents/enacted/data.htm (accessed 14 March 2017) 
House of Lords (2016) https://hansard.parliament.uk/lords/2016-06-

06/debates/16060611000480/CulturalProperty(ArmedConflicts)Bill(HL) (accessed 10 June 2016)

Hufnagel S (2013) Policing Cooperation Across Borders: Comparative Perspectives on Law Enforcement within the EU and Australia. Farnham:Ashgate

ICCROM (2016a) www.iccrom.org/Italys-culture-minister-visits-iccrom/ (accessed 15 July 2016)

ICCROM (2016b) http://www.iccrom.org/new-premises-for-iccrom/ (accessed 15 July 2016)

Johnston L and Shearing C (2003) Governing Security. London:Routledge

Karfeld S (2016) Conference Paper at Art, Crime and Criminals: Painting Fresh Pictures of Art Theft, Fraud and Plunder Workshop, Queen Mary University, London 21 June 2016

Kerr J (2015) The Securitization and Policing of Art Theft: The Case of London.

Farnham:Ashgate

Kerr, J (2014) The Art of Risk Management: The Crucial Role of the Global Art Insurance Industry in Enabling Risk and Security. 1st published 31 October 2014. Journal of Risk Research, Routledge

Le Monde 7/7/2016 http://www.lemonde.fr/culture/article/2016/07/07/le-budget-de-laculture-sera-prioritaire-en-2017-annonce-francois-hollande_4965727_3246.html (accessed 16 July 2016)

Loader I and Walker N (2006) Necessary virtues: the legitimate place of the state in the production of security. In: Wood J and Dupont B (eds) Democracy, Society and the Governance of Security. Cambridge:Cambridge University Press

Mackenzie S (2005) 'Criminal and Victim Profiles in Art Theft: Motive, Opportunity and Repeat Victimisation'. http://ssrn.com/abstract $=1003988$

Mackenzie S and Davis T (2014) Temple Looting in Cambodia Anatomy of a Statue Trafficking Network, British Journal of Criminology, 54:722-740

Mackenzie S and Green P (2009) Criminalising the Market in Illicit Antiquities:an Evaluation of the Dealing in Cultural Objects (Offences) Act 2003 in England and Wales. In Mackenzie $\mathrm{S}$ and Green P (eds) Criminology and Archaeology: Studies in Looted Antiquities.

Oxford:Hart.

McLaughlin E (2007). The New Policing. London:Sage

MiBACT (2016a) http://www.beniculturali.it/mibac/export/MiBAC/sito-MiBAC/MenuUtility/Immagine/index.html_1483290723.html (accessed 15 July 2016) 
MiBACT (2016b) http://www.beniculturali.it/mibac/export/MiBAC/sito-

MiBAC/Contenuti/MibacUnif/Comunicati/visualizza_asset.html_205699155.html (accessed 15 July 2016)

\section{$\operatorname{MiBACT}(2016 \mathrm{c})$}

http://www.beniculturali.it/mibac/multimedia/MiBAC/documents/1420720415719_Call_for_ Applications_for_Directors_of_Museums.pdf (accessed 15 July 2016)

MiBACT (2016d) http://www.beniculturali.it/mibac/export/MiBAC/sitoMiBAC/MenuPrincipale/Ministero/Ministro/Audiovisivi/ (accessed 15 July 2016)

Miller P and Rose N (2008) Governing the Present: Administering Economic, Social and Personal life. Cambridge:Polity

National Wildlife Crime Unit (2016) http://www.nwcu.police.uk/news/nwcu-police-pressreleases/funding-secured-for-national-wildlife-crime-unit-until-2020/ (accessed 26 April 2016)

Parliament (2016) http://www.publications.parliament.uk/pa/cm/cmallparty/151113/culturalheritage.htm (accessed 2 April 2016)

Police Nationale Recrutement OCBC FILM

http://www.dailymotion.com/video/xac38i_office-central-de-lutte-contre-let_news?search_algo=2 (accessed 15 July 2016)

RAI (2015) The Art Detective 08 May 2015 http://www.ufficiostampa.rai.it/dl/UfficioStampa/Articoli/RAI-STORIA-AL-VIA-ARTDETECTIVE-b0ce831d-d4ab-4ce4-bd73-0d7a1ea2dd0e.html

Cap Rapicavoli (2016) Conference Paper at Art, Crime and Criminals: Painting Fresh Pictures of Art Theft, Fraud and Plunder Workshop, Queen Mary University, London 21 June 2016

Reiner R (1992) Policing a Postmodern Society. Modern Law Review, 55(6):761-781.

Reiner R (2010) The Politics of the Police (4th Edition) Oxford:Oxford University Press

Reiner R (2013) Who governs? Democracy, Plutocracy, Science and Prophecy in Policing. Criminology \& Criminal Justice 13(2)161-180

Rush L and Millington L (2015) The Carabinieri Command for the Protection of Cultural Property. Woodbridge:Boydell Press

Serious Fraud Office (2017) www.sfo.gov.uk (accessed 6 January 2017)

Shearing C (2006) Reflections on the Refusal to Acknowledge Private Governments'. In Wood J and Dupont B (eds) Democracy, Society and the Governance of Security. Cambridge:Cambridge University Press 
Shearing C (2015) Reflections on the Nature of Policing and its Development http://www.grgp.uct.ac.za/sites/default/files/image_tool/images/258/Papers/Shearing.\%20201 5.\%20Reflections $\% 20 \mathrm{on} \% 20$ the $\% 20$ nature $\% 20$ of $\% 20$ policing $\% 20$ and $\% 20$ its $\% 20$ developme nt..pdf

Cap. Spadari (2015) Conference Paper at ARCA annual interdisciplinary Art Crime conference in Amelia, Italy, June 26-28

Tsirogiannis C (2016) Reasons to Doubt: Misleading Assertions in the London Antiquities Market, Journal of Art Crime. Spring 2016:67-72

Van Stokkom B and Terpstra J (2016) Plural policing, the public good, and the constitutional state: an international comparison of Austria and Canada-Ontario. Policing and Society: An International Journal of Research and Policy. Published online 11 July 2016

West Mercia Police (2016) https://www.westmercia.police.uk/OperationIcarus (accessed 27 April 2016)

Wood J and Dupont B (eds) (2006) Democracy, Society and the Governance of Security. Cambridge:Cambridge University Press

UNESCO TV (2011) https://www.youtube.com/watch?v=2gOq5SSD9LI (accessed 15 July 2016)

Yates D (2014) Displacement, Deforestation, and Drugs: Antiquities Trafficking and the Narcotics Support Economies of Guatemala. In Kila J and Balcells M (eds) Cultural Property Crimes: an Overview and Analysis on Contemporary Perspectives and Trends. Brill:Leiden 